\title{
Differential element assimilation by sea urchins Paracentrotus lividus in seagrass beds: implications for trophic interactions
}

\author{
F. Tomas ${ }^{1,3, *}$, D. Álvarez-Cascos ${ }^{1}, \mathrm{X}$. Turon $^{2}, \mathrm{~J}_{\text {. Romero }}{ }^{1}$ \\ ${ }^{1}$ Departament d'Ecologia, and ${ }^{2}$ Departament de Biologia Animal (Invertebrats), Universitat de Barcelona, Avenida Diagonal 645, \\ 08028 Barcelona, Spain
}

${ }^{3}$ Present address: Scripps Institution of Oceanography, 9500 Gilman Drive, La Jolla, California 92093-0202, USA

\begin{abstract}
Despite increasing evidence that herbivory in seagrass systems is more important than previously considered, many factors regulating seagrass herbivory still need to be elucidated. In this study we evaluate the importance of epiphytes and seagrass blades in sea urchin nutrition using a multiple stable-isotope approach. Our aim is to contribute to the understanding of plant-herbivore interactions in seagrass beds. Stable-isotope ratios of carbon, nitrogen and sulphur of the sea urchin Paracentrotus lividus (Lamarck) were measured and compared to those of the potential food sources (i.e. the seagrass Posidonia oceanica [L.] Delile and its epiphytes) in a temperate seagrass meadow. Epiphytes and seagrass leaves had distinct $\delta^{13} \mathrm{C}\left(-18.7\right.$ vs. $-12.8 \%$, respectively) and $\delta^{15} \mathrm{~N}$ values (+6.4 vs. $+3.6 \%$, respectively), while values for $\delta^{34} \mathrm{~S}$ were closer $(+19.4 \mathrm{vs} .+17.0 \%$, respectively). Data from $\delta^{13} \mathrm{C}$ and $\delta^{34} \mathrm{~S}$ indicated that both food sources contributed in approximately equal proportions $(50 \%)$ to the bulk organic matter assimilated by Paracentrotus lividus, whereas $\delta^{15} \mathrm{~N}$ measurements showed that approximately $90 \%$ of the nitrogen assimilated by the sea urchin is provided by epiphytes. Given the generally low nutritional quality of $P$. oceanica leaves, the data obtained suggest that epiphyte nitrogen is crucial in regulating the trophic relationships between the herbivore and the seagrass. Thus in P. oceanica meadows, epiphytes, particularly through nitrogen contribution, appear to be an essential component of the diet of important herbivores such as sea urchins.
\end{abstract}

KEY WORDS: Plant-herbivore interactions $\cdot$ Epiphytes $\cdot$ Stable isotopes $\cdot$ Nitrogen $\cdot$ Food quality Mediterranean $\cdot$ Posidonia oceanica

\section{INTRODUCTION}

Herbivory on seagrasses is generally not considered important in regulating plant abundance (Thayer et al. 1984, Valiela 1995) and the amount of plant ingested by grazers usually represents only a minor fraction of the annual net primary production (Thayer et al. 1984, Cebrián \& Duarte 1998). The low consumption rates have been ascribed to the poor nutritional value of plant material expressed by high C:N ratios (Duarte 1990), the inability of most invertebrates to digest cellulose (Lawrence 1975), as well as to the presence of chemical deterrents (Zapata \& McMillan 1979). Never- theless, in connection with the large anthropogenically induced decline in large herbivorous vertebrates such as turtles, sirenians and large fishes, some works have pointed out the lack of historical perspective in examining the importance of herbivory in seagrass systems. These organisms were most probably keystone species in seagrass beds in the past (Thayer et al. 1984, Jackson et al. 2001).

In the Mediterranean, densities of the common sea urchin Paracentrotus lividus (Lamarck) in Posidonia oceanica (L.) Delile meadows are generally low (0 to 6 individuals $\mathrm{m}^{-2}$; see review by Boudouresque \& Verlaque 2001), and seagrass abundance is controlled 
mainly by primary resources (light, temperature and nutrients: Alcoverro et al. 1995). However, as in other seagrass species, some overgrazing events have been reported which, in most cases, have been associated with eutrophication phenomena and sea urchin outbreaks (e.g. Verlaque \& Nédelec 1983, Ruiz et al. 2001).

As shown by feeding-preference experiments and gut-content analyses, in Posidonia oceanica meadows sea urchins feed preferentially on old epiphytised leaves rather than bare seagrass leaves (see review by Boudouresque \& Verlaque 2001). Although sea urchins ingest seagrass leaves and epiphytes simultaneously, the epiphytic flora of $P$. oceanica leaves appear to be the preferred target of Paracentrotus lividus (see review by Boudouresque \& Verlaque 2001), and experimental evidence exists indicating that, even at low densities, sea urchins can control epiphyte biomass (Tomas et al. 2005). This preference for epiphytes may be due to their higher palatability and richer nutritional quality (lower C:N ratios) in comparison to the seagrass material (Alcoverro et al. 1997 for epiphytes, Alcoverro et al. 2000 for seagrass), especially in old leaves, which have the highest $\mathrm{C}: \mathrm{N}$ values (Alcoverro et al. 2000). The epiphytic community of $P$. oceanica leaves consists mainly of microscopic algae, such as crustose red algae (Fosliella spp.) and some typical brown algae of the genera Myrionema, Giraudia and Cladosiphon. Some small animals such as hydrozoans and bryozoans also appear, especially in deeper waters (Ballesteros et al. 1984, Romero 1989).

The alleged preference for epiphytes could indicate that epiphytes are the crucial food resource for sea urchins. However, this hypothesis has rarely been tested (but see Alcoverro et al. 1997 and Tomas et al. 2005) and has received little attention in most macroherbivore-seagrass studies (see reviews by Valentine \& Heck 1999 or Williams \& Heck 2001). A key point to elucidating such interactions is identification of the food sources, not only in terms of ingestion, but also (and mainly) in terms of assimilation. Stable isotopes can help in elucidating aspects of the origin and transformation of the organic matter ingested (e.g. Peterson et al. 1985, Kharlamenko et al. 2001) and can provide a time-integrated measure of trophic position (Vander Zanden \& Rasmussen 2001).

This study evaluates the importance of epiphytes and seagrass blades in sea urchin nutrition using a multiple stable-isotope approach. Our aim is to provide new data for the understanding of plant-herbivore interactions in seagrass beds. Particularly, we compare, in a Posidonia oceanica meadow, the isotopic signatures of ${ }^{13} \mathrm{C},{ }^{15} \mathrm{~N}$ and ${ }^{34} \mathrm{~S}$ between sea urchins and seagrass leaf blades and epiphytes as a means to gaining understanding of diet preferences and the trophic support of sea urchin populations in P. oceanica meadows. In all, our results contribute to elucidating the flow of organic matter from primary producers to herbivores in $P$. oceanica meadows.

\section{MATERIALS AND METHODS}

Study site. The study took place in a Posidonia oceanica meadow located at the Medes Islands (NW Mediterranean) between 5 and $6 \mathrm{~m}$ deep (see Alcoverro et al. 1995, 1997 for detailed description of site). Samples were collected by SCUBA divers at 3 different times during the seasonal cycle of seagrass growth (January and October 2001 and May 2002). May corresponds to the period of maximum leaf growth and production, October represents the period of senescence and loss of leaves and January corresponds to the period of formation of new leaves (Alcoverro et al. 1995). On each occasion, we harvested 6 P. oceanica shoots and 6 adult (5 to $7 \mathrm{~cm}$ test diameter [TD] without spines) sea urchins Paracentrotus lividus, representing the population structure present in this meadow (see Tomas et al. 2004 for more details). These were randomly collected over an area of ca. $500 \mathrm{~m}^{2}$. To avoid any masking effect of development stage, we used exclusively adult sea urchins ( $>5 \mathrm{~cm}$ TD: when individuals reach 5 to $6 \mathrm{~cm}$ TD their growth rate strongly diminishes [Turon et al. 1995]). A sample size of 6 seagrass shoots per sampling was deemed adequate given the usually low levels of variation in isotopic signatures of Mediterranean seagrasses (e.g. Jennings et al. 1997, Lepoint et al. 2000, Pinnegar \& Polunin 2000). Samples were frozen shortly after collection and further processed at the laboratory.

Laboratory processing and analyses. In the laboratory, sea urchins were dissected, and muscles from the Aristotle's lantern were carefully removed and used to perform stable-isotope analyses. Muscle was chosen instead of gonad (the other most abundant tissue) since lipid-rich tissues such as gonads are isotopically lighter owing to discrimination towards ${ }^{12} \mathrm{C}$ during lipogenesis (Van Dover et al. 1992), and this depletion in ${ }^{13} \mathrm{C}$ can potentially reduce the chances of correctly identifying types of source material (Polunin et al. 2001, Post 2002). In addition, lipid tissues have generally fast turnover rates and integrate short-term dietary histories (Polunin et al. 2001), whereas by analysing muscular tissue we can obtain a more integrative measure of assimilated food.

The epiphytes were scraped off the seagrass leaves with a razor blade (Alcoverro et al. 1997). Only the 2 oldest (outermost) leaves of every shoot were separated and used, as they are the most commonly eaten by Paracentrotus lividus under natural conditions 
(Nédelec \& Verlaque 1984). All samples were rinsed with distilled water (Ledent et al. 1995) and then dried at $70^{\circ} \mathrm{C}$ until constant weight $(48 \mathrm{~h}$ approximately). After drying, samples were ground to a fine powder and then sealed in glass vials for later isotope analyses.

Due to the high content of carbonates in the epiphytes (Romero 1989), seagrass material and epiphytes were washed with diluted $\mathrm{HCl}(2 \mathrm{~N})$ to remove carbonates and analyse ${ }^{13} \mathrm{C}:{ }^{12} \mathrm{C}$ ratios of the organic material. As this chemical procedure has been reported to alter the $\delta^{15} \mathrm{~N}$ values (Bunn et al. 1995), for each sample of seagrass and epiphytes, half of the sample was submitted to an acid wash and half remained untreated. Samples washed with acid were used to analyse $\delta^{13} \mathrm{C}$ and untreated samples were used to analyse $\delta^{15} \mathrm{~N}$ and $\delta^{34} \mathrm{~S}$.

Measurements of stable-isotope abundances were performed using a continuous-flow isotope-ratio mass spectrometer Delta C (Thermo Finnigan) coupled to a flash 1112 elemental analyser (Thermo Finnigan) through a Conflo III interfase (Thermo Finnigan). Carbon and nitrogen were analysed in a dual isotope mode and sulphur was analysed separately. Samples of reference material (internal standards) were used to calibrate the system and compensate for drift with time. Experimental precision, based on the standard deviation of replicates of the internal standard, was $0.5 \%$ for $\delta^{13} \mathrm{C}_{\text {, }} 0.5 \%$ for $\delta^{15} \mathrm{~N}$ and $0.2 \%$ for $\delta^{34} \mathrm{~S}$.

Isotope ratios were expressed relative to PeeDee Belemnite (PDB) standard for carbon, to $\mathrm{N}_{2}$ in air for nitrogen, and to Canyon Diablo troilites standard for sulphur. Ratios were calculated as:

$$
\delta X=\left[\left(R_{\text {sample }} / R_{\text {standard }}-1\right)\right] \times 1000
$$

where $X$ is ${ }^{13} \mathrm{C}_{1}{ }^{15} \mathrm{~N}$ or ${ }^{34} \mathrm{~S}$, and $R$ is the corresponding ratio of ${ }^{13} \mathrm{C}:{ }^{12} \mathrm{C},{ }^{15} \mathrm{~N}:{ }^{14} \mathrm{~N},{ }^{34} \mathrm{~S}:{ }^{32} \mathrm{~S}$.

Analysis of data. For an optimal assessment of the importance of Posidonia oceanica and its epiphytes to Paracentrotus lividus nutrition, we used mixing models (Ben-David \& Schell 2001, Phillips \& Gregg 2001) to estimate the proportions of each element assimilated by P. lividus from each food source. Specifically, we pooled the values for all sampling times (see Table 1) to calculate the 2-source mixing model proposed by Phillips \& Gregg (2001) and used the Excel spreadsheet provided by these authors (see www.epa.gov/ wed/pages/models.htm):

$$
\delta \text { consumer }=f_{\mathrm{s} 1} \delta X_{\mathrm{s} 1}+\left(1-f_{\mathrm{s} 1}\right) \delta X_{\mathrm{s} 2}
$$

where $\delta X$ is the mean $\delta^{13} \mathrm{C}_{,}{ }^{15} \mathrm{~N}$ or ${ }^{34} \mathrm{~S}$ value for the consumer or food sources, and $f_{\mathrm{s} 1}$ and $1-f_{\mathrm{s} 1}$ are the proportional inputs of the food sources.

To correct for isotope fractionation across trophic levels, we considered an enrichment of $0.4 \%$ for carbon (Michener \& Schell 1994, Vander Zanden \& Rasmussen 2001, Post 2002), of $3.4 \%$ for nitrogen
(Michener \& Schell 1994, Post 2002) and no enrichment for sulphur (Fry 1988, Michener \& Schell 1994, McCutchan et al. 2003).

To compare isotopic signatures between the 3 sampling times and the organisms, we used a 2-way ANOVA (fixed factors $=$ time and organism). When overall significant differences were detected, a posteriori pairwise comparisons of means was performed using the Student-Newman-Keuls test (SNK: Zar 1984). Prior to statistical analyses, normality and homogeneity of variance were checked for all data (Kolmogorov-Smirnov test and Cochran's test, respectively). If we were unable to attain homoscedasticity even after trying several transformations of the variables studied (indicated in 'Results'), as samples were large, we considered ANOVA to be robust to departures from this assumption (Underwood 1997).

\section{RESULTS}

$\delta^{13} \mathrm{C}, \delta^{15} \mathrm{~N}$ and $\delta^{34} \mathrm{~S}$ signatures were clearly and consistently different among the organisms (seagrass, epiphytes and sea urchins) (Fig. 1, Table 1), whereas a significant interaction between time and organism was found for $\delta^{13} \mathrm{C}$ and $\delta^{15} \mathrm{~N}$ (Table 1), indicating a different temporal trend of the $\mathrm{C}$ and $\mathrm{N}$ isotope signals amongst organisms. While seagrass and epiphytes exhibited a marked seasonal variability in $\delta^{13} \mathrm{C}$, very low seasonality was detected for $\delta^{15} \mathrm{~N}$.

In the $\delta^{13} \mathrm{C}$ versus $\delta^{34} \mathrm{~S}$ plot (Fig. 2a), generally considered the most informative in resolving food sources

Table 1. Summary of factorial 2-way ANOVA to assess significant differences in isotopic signatures between sampling times (October, January and May) and organisms (seagrass Posidonia oceanica leaves, epiphytes and sea urchins Para-

\begin{tabular}{|c|c|c|c|c|c|}
\hline Variable & Effect & $\mathrm{df}$ & MS & $F$ & p-level \\
\hline \multirow[t]{4}{*}{$\delta^{13} \mathrm{C}$} & Time (T) & 2 & 0.147 & 0.433 & $\mathrm{~ns}$ \\
\hline & Organism (O) & 2 & 148.168 & 435.241 & $<0.0001$ \\
\hline & $\mathrm{T} \times \mathrm{O}$ & 4 & 5.561 & 16.336 & $<0.0001$ \\
\hline & Error & 41 & 0.340 & & \\
\hline \multirow[t]{4}{*}{$\delta^{15} \mathrm{~N}^{\mathrm{a}}$} & Time $(\mathrm{T})$ & 2 & 0.609 & 2.811 & $\mathrm{~ns}$ \\
\hline & Organism (O) & 2 & 147.963 & 682.394 & $<0.0001$ \\
\hline & $\mathrm{T} \times \mathrm{O}$ & 4 & 1.584 & 7.304 & $<0.0001$ \\
\hline & Error & 41 & 0.217 & & \\
\hline \multirow[t]{4}{*}{$\delta^{34} \mathrm{~S}^{\mathrm{a}}$} & Time $(\mathrm{T})$ & 2 & 6.454 & 7.086 & 0.002 \\
\hline & Organism (O) & 2 & 26.518 & 29.114 & $<0.0001$ \\
\hline & $\mathrm{T} \times \mathrm{O}$ & 4 & 2.168 & 2.380 & $\mathrm{~ns}$ \\
\hline & Error & 42 & 0.911 & & \\
\hline
\end{tabular}
centrotus lividus) and their interactions. ns = not significant 


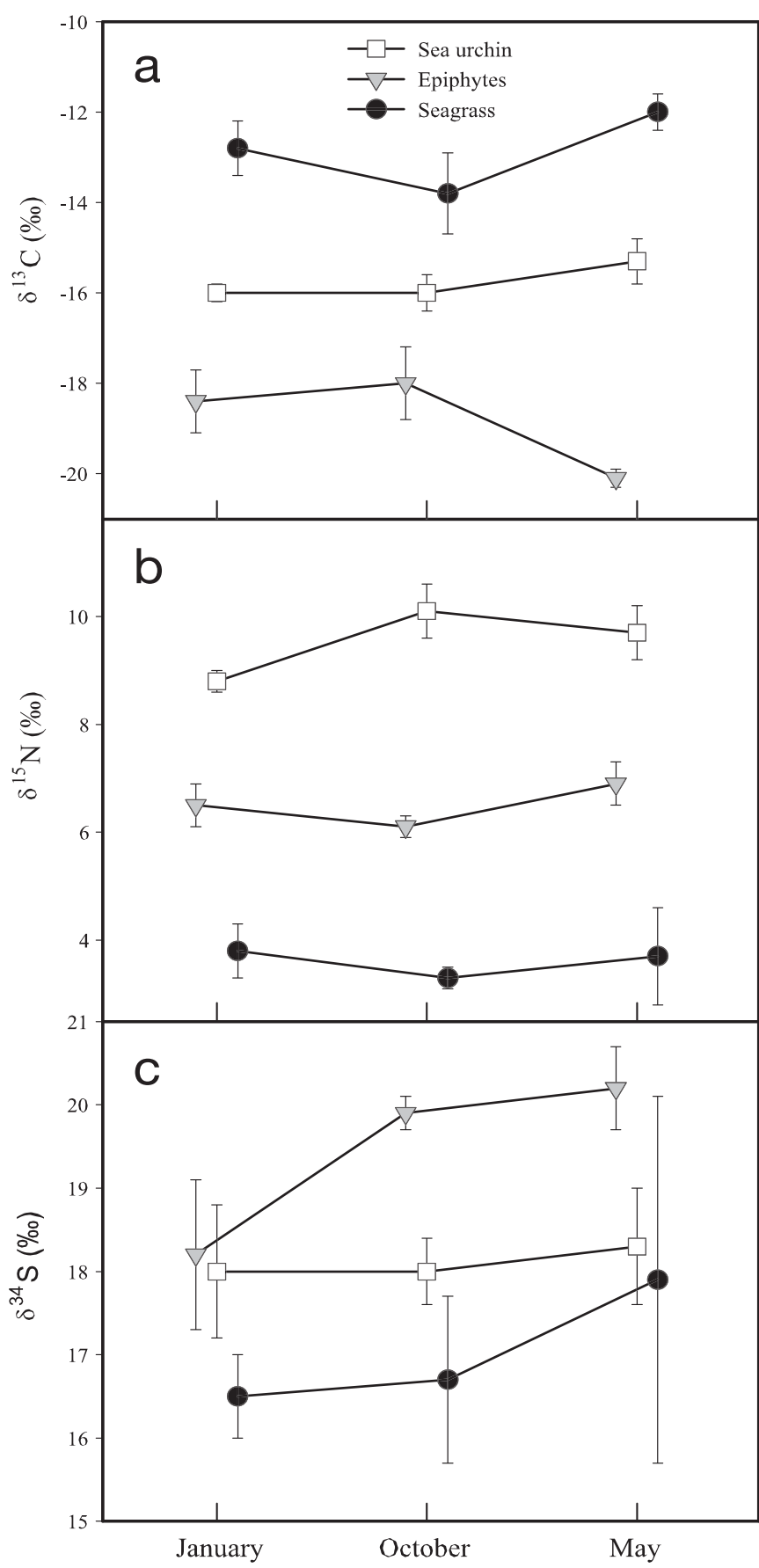

Fig. 1. Paracentrotus lividus. Time course of stable isotope ratios (mean $\pm \mathrm{SD}$ ) of (a) carbon, (b) nitrogen and (c) sulphur for sea urchin and its 2 main food sources, the seagrass Posidonia oceanica and its epiphytes

(Peterson et al. 1985, Kwak \& Zedler 1997), Paracentrotus lividus composition appeared in an intermediate position relative to the potential food sources, indicating nearly equal proportions of both. In contrast, taking into account the trophic shift of $3.4 \%, \delta^{15} \mathrm{~N}$ of the

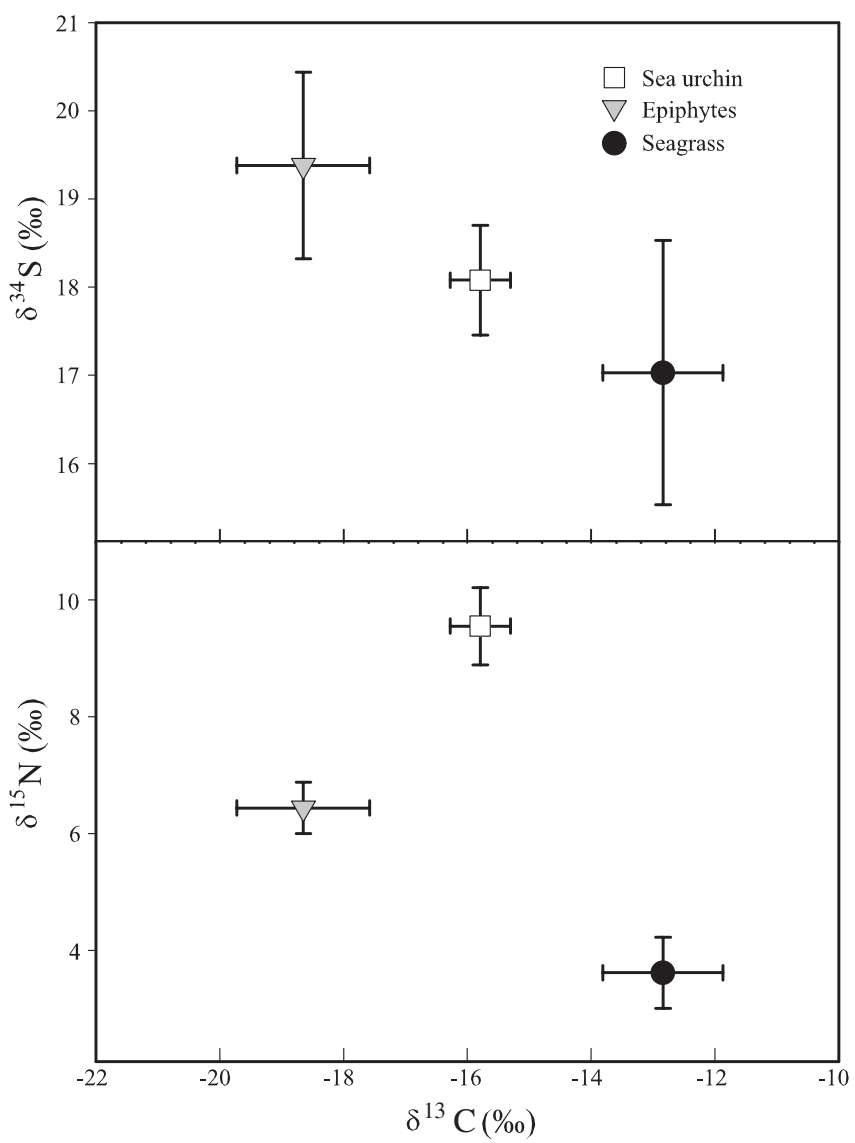

Fig. 2. Paracentrotus lividus. Stable-isotope plots of mean $\delta^{13} \mathrm{C}, \delta^{15} \mathrm{~N}$ and $\delta^{34} \mathrm{~S}$ (mean $\pm \mathrm{SD}$ ) for sea urchin and its 2 main food sources, the seagrass Posidonia oceanica and its epiphytes

sea urchin was much closer to epiphyte values than to seagrass values (Fig. 2b).

Using the linear model described by Phillips \& Gregg (2001), we estimated that Posidonia oceanica provides $56 \pm 4(\mathrm{SE}) \%$ of the carbon assimilated by Paracentrotus lividus, whereas the epiphytes provide the other $44 \pm 4(\mathrm{SE}) \%$. Similar results were obtained for $\mathrm{S}$, i.e. the contribution of seagrass was $56 \pm 11$ (SE) $\%$ and the contribution of epiphytes was $44 \pm 11$ (SE)\%. In contrast, the assimilation of nitrogen was noticeably skewed towards the epiphytes $-90 \pm 7(\mathrm{SE}) \%$ of the nitrogen being provided by the epiphytes and only $10 \pm 7(\mathrm{SE}) \%$ by the seagrass itself.

\section{DISCUSSION}

The results of this study suggest that in Posidonia oceanica meadows the contribution of epiphytes to the diet of Paracentrotus lividus is very important, especially in regard to nitrogen. For carbon, the results 
indicate that $P$. lividus obtains approximately half of its carbon from $P$. oceanica and the other half from the epiphytes. The same result was obtained by Kharlamenko et al. (2001) for grazing gastropods in a Zostera marina community. The results for sulphur confirm that both food sources contribute in approximately equal proportions to the bulk organic matter assimilated by sea urchins, while a markedly different pattern was observed for nitrogen, for which it seems that the contribution of the epiphytes greatly outweighs that of the seagrass.

In this study, we assumed that seagrass material and its epiphytes are the only 2 main food sources for Paracentrotus lividus. Nevertheless, other potential food sources that we have not taken into consideration (macroalgae attached to rhizomes or particulate organic matter) could have influenced the stable-isotope ratios observed. This influence, if any, should be only marginal. Macroalgae living on rhizomes are only rarely found in the guts of $P$. lividus (generally $<1 \%$ dry weight: Nédelec \& Verlaque 1984). Indeed, macroalgae on rhizomes are scarce in the meadow studied (Ballesteros et al. 1984) and can be dismissed as an important food source. We confirmed this by examining the gut contents of the sea urchins collected. The capacity to directly absorb particulate organic matter through the epidermis has been described for various echinoderm species (Péquignat 1972). However, this material is generally highly refractory and does not appear to be an attractive food source in terms of nutritional quality. In addition, if not highly processed, such organic matter should have a signature similar to its original material, mostly epiphytes or seagrass. $P$. lividus exhibits little migration (Dance 1987, Sala \& Zabala 1996), especially in Posidonia oceanica meadows, where sea urchins travel significantly less than on rocky substrates (Boudouresque \& Verlaque 2001). Therefore, it is unlikely that, in the meadow studied, $P$. lividus feeds on food sources other than seagrass and epiphytes, since the meadow is very homogeneous with no rocky outcrops to which urchins might migrate to feed.

Other factors which could also have modified our results are the enrichment values used in the mixing models. For $\mathrm{C}$ and $\mathrm{S}$, the range of variation is relatively low (ca. 0.5 to $1 \%$ for C: Fry 1988, Michener \& Schell 1994, McCutchan et al. 2003; ca. 0 to $1 \%$ for S: Peterson et al. 1985, Fry 1988, Van Dover et al. 1992, Michener \& Schell 1994, McCutchan et al. 2003); and hence the conclusion of equivalent contributions of both food sources to the bulk of organic matter is valid. For nitrogen, the variation in the enrichment factor at each trophic level appears to be larger, generally ranging between ca. 2 and $4 \%$ (Fry 1988, Michener \& Schell, 1994, McCutchan et al. 2003, Vanderklift \& Ponsard
2003). Nevertheless, had we used a different enrichment factor within this range, the conclusion that epiphytes are the main suppliers of nitrogen assimilated by sea urchins would have remained, since the contribution of nitrogen would still have been markedly skewed towards epiphytes (ca. 70 to $100 \%$ ).

Considering that nitrogen concentrations are similar in old Posidonia oceanica leaves and its epiphytes (1 to $2 \%$ dry weight: Alcoverro et al. 1997, 2000), the higher contribution of epiphytes to nitrogen in sea urchins suggests that, although Paracentrotus lividus is ingesting both seagrass leaves and its epiphytes, there is a differential assimilation of the elements. Furthermore, the C:N ratio of seagrass leaves is approximately double that of epiphytes (ca. 29 and 12, respectively: Alcoverro et al. 1997, 2000). Therefore, since the contribution by seagrass and epiphytes to sea urchin $\delta^{13} \mathrm{C}$ is approximately $1: 1$, sea urchins appear to assimilate epiphyte nitrogen preferentially over seagrass nitrogen at a ratio (9:1) well above that which could be explained by the relatively higher availability of nitrogen per unit carbon for epiphytes compared with the seagrass (2.5:1). This supports our hypothesis of differential assimilation between epiphytes and seagrass nitrogen by sea urchins, as has been suggested for other animal species in diverse systems (Gannes et al. 1997, Koch \& Phillips 2002, Post 2002).

Epiphytes appear to have a higher nutritional quality than seagrass. On the one hand (and as indicated by the $\mathrm{C}: \mathrm{N}$ values), most of the total carbon content in seagrasses is in the form of cellulose and other structural components (Duarte 1990) that cannot be easily utilised by animals; on the other hand, the fraction of assimilable-nitrogen components is lower in old Posidonia oceanica leaves. On average, soluble nitrogen compounds in old leaves account for only $0.7 \%$ dry weight (Invers et al. 2002); hence a very important fraction of the nitrogen in old leaves available to sea urchins comprises structural refractory nitrogen. Therefore, although $\mathrm{N}$ concentrations are similar in both food sources, the availability of this $\mathrm{N}$ differs, which could explain the observed 'preferential' assimilation of epiphytic nitrogen.

It is generally believed that plant quality is a main factor limiting consumer feeding rates across communities and that communities in which plants have a higher nutritional value support higher losses to herbivory (Cebrián 1999). Some authors have also suggested that feeding intensity on seagrasses is determined by nitrogen availability, rather than by the carbon content of their leaves (Bjorndal 1980, McGlathery 1995, Ruiz 2000). Our results seem to support this, and point to nitrogen contained in epiphytes as a key factor in the trophic relationships in our system. Our results could explain the reported preference 
of sea urchins for epiphytised leaves (see review by Boudouresque \& Verlaque 2001). The importance of the nitrogen content of epiphytes has also been shown in a Syringodium isoetifolium seagrass bed by Yamamuro (1999), who observed a strong dependence of herbivores on epiphytic cyanobacteria and attributed this phenomenon to the relative differences in nitrogen content of the different organic materials.

In the system studied herein, the stable-isotope data obtained supports the hypothesis that grazing on seagrasses is driven by nitrogen availability, and specifically by the nitrogen content of epiphytes. Our study points to the importance of epiphytes in herbivore-seagrass interactions, a potential key factor that has not received full attention in the study of seagrass herbivory in other systems.

Acknowledgements. This work was supported by grant REN2002-04020-C02-02/MAR and GRC 2001 SGR 00093. We thank E. Cruz, P. López-Sendino and E. Rovira for field and laboratory assistance and M. A. Mateo, G. Lepoint and D. Phillips for comments and advice. Stable-isotope analyses were performed in the 'Serveis Científico-Tècnics de la Universitat de Barcelona'.

\section{LITERATURE CITED}

Alcoverro T, Duarte C, Romero J (1995) Annual growth dynamics of Posidonia oceanica: contribution of large-scale versus local factors to seasonality. Mar Ecol Prog Ser 120: 203-210

Alcoverro T, Duarte C, Romero J (1997) The influence of hervibores on Posidonia oceanica epiphytes. Aquat Bot 56: 93-104

Alcoverro T, Manzanera M, Romero J (2000) Nutrient mass balance of the seagrass Posidonia oceanica: the importance of nutrient retranslocation. Mar Ecol Prog Ser 194: $13-21$

Ballesteros E, García-Rubies A, Lobo A, Romero J (1984) L'alguer de Posidonia oceanica de les Iles Medes. In: Ros J, Olivella I, Gili JM (eds) Els sistemes naturals de les Illes Medes. Institut d'Estudis Catalans, Barcelona, p 739-759

Ben-David M, Schell DM (2001) Mixing models in analyses of diet using multiple stable isotopes: a response. Oecologia 127:180-184

Bjorndal KA (1980) Nutrition and grazing behaviour of the green turtle Chelonia mydas. Mar Biol 56:147-154

Boudouresque CF, Verlaque M (2001) Ecology of Paracentrotus lividus. In: Lawrence JM (ed) Edible sea urchins: biology and ecology, Vol 32. Elsevier, Amsterdam, p $177-216$

Bunn SE, Loneragan N, Kempster MA (1995) Effects of acid washing on stable isotope ratios of $\mathrm{C}$ and $\mathrm{N}$ in penaeid shrimp and seagrass: implications for food-web studies using multiple stable isotopes. Limnol Oceanogr 40: 622-625

Cebrián J (1999) Patterns in the fate of production in plant communities. Am Nat 154:449-468

Cebrián J, Duarte CM (1998) Patterns in leaf herbivory on seagrasses. Aquat Bot 60:67-82

Dance C (1987) Patterns of activity of the sea urchin Para- centrotus lividus in the Bay of Port-Cros (Var, France, Mediterranean). PSZN I: Mar Ecol 8:131-142

Duarte CM (1990) Seagrass nutrient content. Mar Ecol Prog Ser 67:201-207

Fry B (1988) Food web structures on Georges Bank from stable $\mathrm{C}, \mathrm{N}$ and S isotopic compositions. Limnol Oceanogr 33: $1182-1190$

Gannes LZ, O'Brien DM, Martínez del Rio C (1997) Stable isotopes in animal ecology: assumptions, caveats, and a call for more laboratory experiments. Ecology 78:1271-1276

Invers O, Pérez M, Romero J (2002) Seasonal nitrogen speciation in temperate seagrass Posidonia oceanica (L.) Delile. J Exp Mar Biol Ecol 273:219-240

Jackson JBC, Kirby MX, Berger WH, Bjorndal KA and 10 others (2001) Historical overfishing and the recent collapse of coastal ecosystems. Science 293:629-638

Jennings S, Reñones O, Morales-Nin B, Polunin NVC, Moranta J, Coll J (1997) Spatial variation in the ${ }^{15} \mathrm{~N}$ and ${ }^{13} \mathrm{C}$ stable isotope composition of plants, invertebrates and fishes on Mediterranean reefs: implications for the study of trophic pathways. Mar Ecol Prog Ser 146:109-116

Kharlamenko VI, Kiyasho SI, Imbs AB, Vyshkvartzev DI (2001) Identification of food sources of invertebrates from the seagrass Zostera marina community using carbon and sulfur stable isotope ratio and fatty acid analyses. Mar Ecol Prog Ser 220:103-117

Koch PL, Phillips DL (2002) Incorporating concentration dependence in stable isotope mixing models: a reply to Robbins, Hilderbrand and Farley (2002). Oecologia 133: $14-18$

Kwak TJ, Zedler JB (1997) Food web analysis of southern California coastal wetlands using multiple stable isotopes. Oecologia 110:262-277

Lawrence J (1975) On the relationship between marine plants and sea urchins. Oceanogr Mar Biol Annu Rev 13:213-286

Ledent G, Mateo MA, Warnau M, Temara A, Romero J, Dubois P (1995) Element losses following distilled water rinsing of leaves of the seagrass Posidonia oceanica (L.) Delile. Aquat Bot 52:229-235

Lepoint G, Nyssen F, Gobert S, Dauby P, Bouquegneau JM (2000) Relative impact of a seagrass bed and its adjacent epilithic algal community in consumer diets. Mar Biol 136: 513-518

McCutchan JH, Lewis WM Jr, Kendall C, McGrath CC (2003) Variation in trophic shift for stable isotope ratios of carbon, nitrogen, and sulfur. Oikos 102:378-390

McGlathery KJ (1995) Nutrient and grazing influences on a subtropical seagrass community. Mar Ecol Prog Ser 122: $239-252$

Michener RH, Schell DM (1994) Stable isotope ratios as tracers in marine aquatic food webs. In: Latjha K, Michener $\mathrm{RH}$ (eds) Stable isotopes in ecology and environmental sciences. Blackwell Scientific Publications, Oxford, p 316

Nédelec H, Verlaque M (1984) Alimentation de l'oursin Paracentrotus lividus (Lamarck) dans un herbier à Posidonia oceanica (L.) Delile en Corse (Mediterranée, France). In: Boudouresque CF, Jeudy de Grissac A, Olivier J (eds) International Workshop Posidonia oceanica Beds. GIS Posidonie, Marseille, p 349-364

Péquignat E (1972) Some new data on skin-digestion and absorption in urchins and sea stars (Asterias and Henricia). Mar Biol 12:28-41

Peterson BJ, Howarth RW, Garrit RH (1985) Multiple stable isotopes used to trace the flow of organic matter in estuarine food webs. Science 227:1361-1363

Phillips DL, Gregg JW (2001) Uncertainty in source partitioning using stable isotopes. Oecologia 127:171-179 
Pinnegar JK, Polunin NVC (2000) Contributions of stableisotope data to elucidating food webs of Mediterranean rocky littoral fishes. Oecologia 122:399-409

Polunin NVC, Morales-Nin B, Pawsey WE, Cartes JE, Pinnegar JK, Moranta J (2001) Feeding relationships in Mediterranean bathyal assemblages elucidated by stable nitrogen and carbon isotope data. Mar Ecol Prog Ser 220: $13-23$

Post DM (2002) Using stable isotopes to estimate trophic position: models, methods and assumptions. Ecology 83: $703-718$

Romero J (1989) Epífitos de las hojas de Posidonia oceanica: variaciones estacionales y batimétricasde biomasa en la pradera de las Islas Medes (Girona). Oecol Aquat 9:19-25

Ruiz JM (2000) Respuesta de la Panerógama marina Posidonia oceanica (L.) Delile a perturbaciones antrópicas. PhD dissertation, University of Muraa, Muraa

Ruiz JM, Pérez M, Romero J (2001) Effects of fish farm loading on seagrass (Posidonia oceanica). Distribution, growth and photosynthesis. Mar Pollut Bull 42:749-760

Sala E, Zabala M (1996) Fish predation and the structure of the sea urchin Paracentrotus lividus populations in the NW Mediterranean. Mar Ecol Prog Ser 140:71-81

Thayer GW, Bjorndal KA, Odgen JC, Williams SL, Zieman JC (1984) Role of larger herbivores in seagrass communities. Estuaries 7:351-376

Tomas F, Romero J, Turon X (2004) Settlement and recruitment of the sea urchin Paracentrotus lividus in two contrasting habitats in the Mediterranean. Mar Ecol Prog Ser 282:173-184

Tomas F, Turon X, Romero J (2005) Effects of herbivores on a Posidonia oceanica seagrass meadow: importance of epiphytes. Mar Ecol Prog Ser 287:115-125

Turon X, Giribert G, López S, Palacín C (1995) Growth and

Editorial responsibility: Otto Kinne (Editor-in-Chief),

Oldendorf/Luhe, Germany population structure of Paracentrotus lividus (Echinodermata: Echinoidea) in two contrasting habitats. Mar Ecol Prog Ser 122:193-204

Underwood AJ (1997) Experiments in ecology. Cambridge University Press, Cambridge

Valentine JF, Heck KL Jr (1999) Seagrass herbivory: evidence for the continued grazing of marine grasses. Mar Ecol Prog Ser 176:291-302

Valiela I (1995) Marine ecological processes. Springer-Verlag, New York

Vanderklift M, Ponsard S (2003) Sources of variation in consumer-diet $\delta^{15} \mathrm{~N}$ enrichment: a meta-analysis. Oecologia 136:169-182

Vander Zanden MJ, Rasmussen JB (2001) Variation in $\delta^{15} \mathrm{~N}$ and $\delta^{13} \mathrm{C}$ trophic fractionation: implications for aquatic food webs studies. Limnol Oceanogr 46:2061-2066

Van Dover CL, Grassle JF, Fry B, Garrit RH, Starczak VR (1992) Stable isotope evidence for entry of sewagederived organic material into a deep-sea food web. Nature 360:153-155

Verlaque M, Nédelec H (1983) Note préliminaire sur les relations biotiques Paracentrotus lividus (LMK.) et herbier de posidonies. Rapp P-V Réun Comm Int Explor Mer Méditerr 28:157-158

Williams SL, Heck KL Jr (2001) Seagrass community ecology. In: Bertness MD, Gaines SD, Hay ME (eds) Marine community ecology. Sinauer, Sunderland, MA, p 317-337

Yamamuro M (1999) Importance of epiphytic cyanobacteria as food sources for heterotrophs in a tropical seagrass bed. Coral Reefs 18:263-271

Zapata O, McMillan C (1979) Phenolic acids in seagrasses. Aquat Bot 7:307-317

Zar JH (1984) Biostatistical analysis. Prentice-Hall, Englewood Cliffs, NJ

Submitted: December 17, 2003; Accepted: May 3, 2005

Proofs received from author(s): December 6, 2005 